\section{God lærebok for målgruppen}

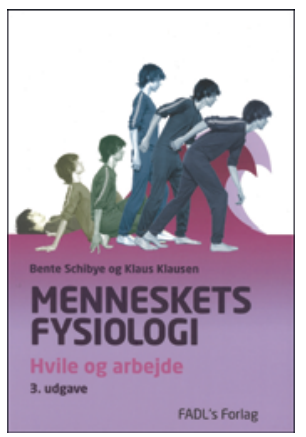

Bente Schibye, Klaus Klausen

Menneskets fysiologi

Hvile og arbeide. 3. utg. 460 s, tab, ill. København: FADL's Forlag, 2011. Pris DKK 570 ISBN 978-87-7749-613-4

Målgruppen er studenter i bl.a. fysioterapi, ergoterapi og idrettsfag, noe forfatterne har tatt hensyn til $i$ vektleggingen av stoffet $i$ de forskjellige kapitlene. De hevder i forordet at boken dekker hele menneskets fysiologi, både i hvile og under fysisk aktivitet, og at den er oppdatert med hensyn til nyere forskningsresultater.

Hvor omfattende oppdateringen har vært, er ikke godt å vite, når lærebøker - og denne er intet unntak - ikke inneholder litteraturreferanser. For eksempel angis et høyere antall gener (50 000-100 $000)$ i det humane genom enn det man ellers gjerne regner med (ca. 22 000), og hvordan luktceller stimuleres, er ikke kommet med. Men rett skal være rett, astrocyttenes betydning for miljøet rundt hjernens synapser er der, likeledes muligheten for at stamceller i hjernen kan danne nye nevroner også i den aldrende hjernen. Hvis mus holdes i et aktivt miljø, hvor hippocampus aktiveres, økes nydanningen av nerveceller, og fysisk aktivitet stimulerer så vel innlæringsevnen som nydanningen av nerveceller. Stresses den, kan man derimot se et fall i celledelingen og innlæringsevnen. Forfatterne ser holdepunkter for at dette også gjelder mennesker. Vel og bra!

Boken er velskrevet og lettlest, selv for en nordmann, og pedagogisk grei, ved at nesten hvert kapittel har emneangivelse i margen, stikkord i teksten er kursivert, og det er mange skjematiske figurer som godt forklarer de fysiologiske prinsippene. Spesielle emner, som speilnevroner, Parkinsons sykdom, glykemisk indeks, diabetes og fysisk aktivitet er omtalt i «bokser». Jeg har ikke noe negativt å si om layout, papir, innbinding eller den 22 sider lange indeksdelen.

Kapitlene avsluttes med et «test deg selv»-avsnitt, med korte faktaspørsmål og essayoppgaver, som begge holdes på et lavt taksonomisk nivå. Boken har et tillegg med oversikt over måleenheter, elementær kjemi og forkortelser.

Når det angis at boken også med fordel kan leses av medisinstudenter som er interessert i samspillet mellom kroppens funksjoner i hvile og under arbeid, tar forfatterne etter min mening kanskje munnen for full, selv om de behandler idrettsfysiologien ganske detaljert og har med meget interessant stoff som har med motorikken å gjøre.

Man kan kanskje innvende at boken slett ikke dekker hele menneskets fysiologi når for eksempel tykktarmen og mosjonens påvirkning på tarmkanalen ikke er med, og heller ikke - eller nesten ikke - miksjon, forplantning og immunreaksjoner.

For den egentlige målgruppen tror jeg denne læreboken er meget velegnet. For leger og medisinstudenter, som bør være vant til å stille spørsmålet «Hvordan vet du det?», er det kanskje bedre å søke svar andre steder.

\section{Haakon Breien Benestad}

Avdeling for fysiologi

Institutt for medisinske basalfag

Universitetet i Oslo

\section{Nyttig, men lite nøkternt}

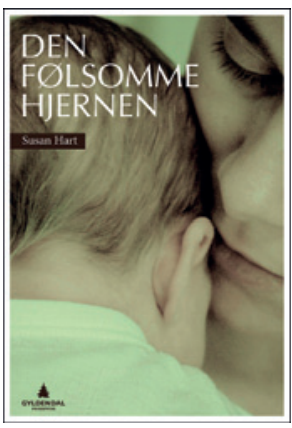

Susan Hart

Den følsomme hjernen

236 s, ill. Oslo: Gyldendal akademisk, 2011

Pris NOK 345

ISBN 978-82-05-41588-1

Den følsomme hjernen er en av flere bøker der den danske psykologen Susan Hart populariserer kunnskap om hjernen og om utvikling for et helsefaglig publikum.

I denne boken gjennomgår hun hjernens plastisitet og utviklingspotensial. Hun viser hvordan man med hjelp av ny teknologi, spesielt ulike teknikker for avbildning av hjernen, på en helt annen måte enn før kan bygge bro mellom nevrobiologi, psykoanalyse og utviklingspsykologi, og hvordan dette danner grunnlaget for nevroaffektiv utviklingspsykologi og terapi.

Dette er en grundig innføring i de deler av hjernen som er viktige for samspill, personlighetsutvikling og følelsesliv. Forfatteren søker å gi en forståelse av hvordan nervesystemet er i stand til å utvikle innlevelse, mentalisering og refleksjon, noe som gir oss mulighet til å tenke om fortid og fremtid og forholde oss meningsfylt til alt fra mellommenneskelige relasjoner til etikk, kunst og estetikk.

Komposisjonen er god. De første seks kapitlene handler om hjernens natur, adapsjon og oppbygging. De neste seks omhandler menneskets evne til samhørighet, om samspillets betydning for hjernens utvikling og om konsekvensene av manglende samhørighet og trygge relasjoner. Boken avsluttes med tre kapitler om psykoterapi.

Kapitlene er godt strukturert, med gode illustrasjoner og kliniske eksempler. Hvert kapittel innledes med nydelige små sitater av sentrale bidragsytere til feltet, som Antonio Damasio, Allan Schore og Daniel Stern. Sitatene er tematisk godt flettet inn i budskapet til de respektive kapitlene.

Hart skriver med kunnskap om, og interesse for, stoffet hun formidler. Hun balanserer godt mellom forskning og egen og andres tenkning. Som kritisk leser savner jeg likevel kildehenvisninger og referanser til mange av påstandene.

Språket er tungt og i tillegg dårlig oversatt, noe som ødelegger helhetsinntrykket. Flere ganger bruker man danske originaluttrykk der man med letthet kunne satt inn gode norske ord. Et eksempel er «anbringelse» i stedet for «plassering i fosterhjem».

En sentral innvending er at forfatteren, selv om hun viser både klinisk skjønn og god teoretisk forståelse, kan virke lite nøktern, ja av og til nesten tendensiøs, i sine konklusjoner. Nevrobiologisk forskning er inne i en historisk produktiv fase. Nettopp derfor bør man utvise forsiktighet med å trekke vidtrekkende konklusjoner på bakgrunn av enkeltstudier og tentative sammenhenger. Det er av og til en tynn linje mellom spekulasjon og empiri. Langt fra alltid tydeliggjør forfatteren på hvilken side av denne linjen hun befinner seg. Dette gjør at man på flere punkter blir skeptisk til budskapet.

Til tross for disse svakhetene er boken absolutt leseverdig. Jeg anbefaler den spesielt for psykologer og psykiatere som ønsker å orientere seg i ny kunnskap om hjernen, og generelt for leger med interesse for utviklingspsykologiens nevrobiologi. Boken gir kunnskap som kan brukes både psykoedukativt, i terapeutisk arbeid med barn, voksne og par, og som generell bakgrunn for forståelse av psykologisk endringsarbeid.

Gro Vatne Brean

Regionsenter for barn og ungdoms psykiske helse R-BUP øst og sør Oslo 